\title{
Dietary Practices Of Older Children With Sickle Cell Disease At The Sickle Cell Center, Benin City, Nigeria
}

\author{
Edet-Utan Oluwakemi ${ }^{1}$, Aina Racheal ${ }^{2}$, Mathew Olayemi ${ }^{3}$ \\ ${ }^{1} \mathrm{PhD}$, Texila American University, Nigeria \\ ${ }^{2}$ Hospital Management Board, General Hospital, Omuo Ekiti \\ ${ }^{3}$ Institute of Human Virology Nigeria, Asaba regional office, University of Benin \\ Teaching Hospital, Benin City, Edo state \\ Email: tomry2001@yahoo.com
}

\begin{abstract}
Nutrient needs are higher during adolescence and those with sickle cell disease require a diet that provides plenty of calories, protein, vitamins and minerals. It is therefore pertinent to study the dietary practices of older children who are mainly adolescents with sickle cell disease. This study took place at the sickle cell center Benin City, Edo state using a cluster of clients who are adolescents within the study period of 4 weeks. Clients who participated in this study were both out-patient and in-patients.

A total of 60 clients were interviewed using an interviewer/self administered questionnaire with $51.7 \%$ females and $66.6 \%$ were 15 years or less. Although $83.3 \%$ of the adolescents reportedly take adequate diet, only 35\% include fresh vegetables, $41 \%$ include fresh fruits, $15 \%$ include wheat and $17 \%$ include beans in their daily diet. Majority (68.3\%) reportedly take 'special diet' only when in crisis. This study has shown that adolescents under study do not adequately eat diet that are beneficial to their health and good sources of macro and micronutrients evidenced by the poor irregular intake of fruits, vegetables, beans and wheat products though they claimed to be taking adequate diet. Consequently, emphasis need to be placed on intake of adequate nutritious diet regularly and not just the intake of 'special diet' when they are in crisis.
\end{abstract}

Keywords: Sickle cell disease, adolescents, older children, diet, nutrients

\section{Introduction}

Undernutrition has been considered as a serious complication and should be a part of the clinical care (de Franceschi et al, 2000; Tomer et al, 2001). There is also growing interest in finding nutritional alternatives to solving problems of persons with sickle cell disease but little is known about adolescent with sickle cell and their dietary practices in Nigeria. Adolescents with sickle cell disease are at risk of growth and nutritional deficiencies due to poor dietary intake (Ashara, 2013). Therefore, the purpose of this study is to assess the dietary practices of older children who are mainly adolescents with SCD.

\section{Objective of the Study}

The main objective of the study was to assess dietary practices of adolescents with sickle cell disease (SCD) attending Sickle Cell Center, Benin City (SCCBC) within the 4-week study period (October/November, 2009).

\section{Methodology}

A descriptive research design was used for this study. It was designed to assess pattern of dietary intake among older children who are mostly adolescents with SCD in view of their nutrition

\section{Study Setting}

This study was carried out in Sickle Cell Center, Sir Gabriel Avenue, Benin City, Edo State. The center is located in the Government Reserved Area (GRA) in Benin City. It was 
established on Wednesday $26^{\text {th }}$ of May 1993 and was commissioned by the President of Nigeria, General Ibrahim Babangida. This centre consists of both male and female wards with six beds respectively. It consists of Sickle Cell Club, with the Permanent Secretary's office and the office of Commissioner for Health, Edo State. The hospital was selected because it is a tertiary institution that renders preventive, promotive, curative and rehabilitative health care services to clients with sickle cell disease. Secondly, it has up-to-date statistical records with more focus on the sickle cell clients. It has a high patronage of sickle cell patients because of the special attention, low cost treatment and services rendered.

\section{Target Population}

The target population comprised all older children with genotype HbSS and HbSC who received in-patient and out-patient care in the Sickle Cell Center, Benin City Edo State during the 4-week period of the study, October/ November, 2009. All respondents were within 8 to 19 years.

\section{Sample and Sampling Technique}

A sample size of 60 respondents was drawn from the target population using a cluster sampling technique in which all older children who satisfy the inclusion criteria during the period of study were interviewed. The inclusion criteria are;

- Older children (8 - 19 years) who attended the outpatient clinic within the study period

- Older children ( 8 - 19 years) who were admitted within the period of 4 weeks (October/ November, 2009)

\section{Instrument for data collection}

Data for this study was collected using a questionnaire developed by the researcher questionnaire in order to achieve the objectives of this study. This questionnaire consists of four sections including:

1. Socio-demography data consisting of age, sex, occupation, position in family.

2.Pattern of dietary practices.

\section{Validity of instrument}

Care givers at the centre scrutinized the questionnaire thoroughly before it was administered to respondents. Expert opinions were also sought from senior colleagues who are vast in managing patients with sickle cell disease. This was done in other to ensure validity of the instrument.

\section{Method of Data Collection}

Letter of approval was given by the Chief Medical Director at the Sickle Cell Center Benin City, Edo State prior to data collection. Verbal consent of respondents was obtained prior to administering the questionnaire. The self- administered questionnaire was distributed to adolescents, who attended the outpatient clinic of the centre as well as those on admission for a period of 4 weeks (October /November, 2009). While for those who could not read the content of the questionnaire, it was interviewer administered. About 10 minutes was given to each respondents to fill the questionnaire especially those requiring re-call after which the researcher cross-checked for omissions and to explain some contents.

\section{Method of data analysis}

Data obtained was analyzed using Statistical Package for Social Science (SPSS) for window 15.0 version to generate tables and charts

\section{Ethical considerations}

Permission to carry out the study was obtained from the Chief Medical Director in Sickle Cell Center. The parent or significant other of the patient provided permission before including the patient in the study. Verbal consent of respondents was obtained prior to 
administering the questionnaire. The purpose of the research was disclosed to the respondents. The sections included in the questionnaire were explained clearly in a simple language. Anonymity and confidentiality of individual respondents were maintained throughout the study.

\section{Results}

Table 1 shows the socio-demographic characteristics of respondents. Respondents between the ages of $8-11$ years were $14(23.3 \%), 12-15$ years were $26(43.3 \%)$, and $16-19$ years accounted for 20(33.3\%). All the respondents were students and majorities were Christian. Respondents with primary, secondary and tertiary level of education were 23(38.3\%), $34(56.7 \%)$, and $3(5.0 \%)$ respectively. Regarding the birth order of respondents in the family, $25 \%$ were $1^{\text {st }}, 16.7 \%$ were $2^{\text {nd }}, 16.7 \%$ were also $3^{\text {rd }}, 23.3 \%$ were $4^{\text {th }}$, and $18.3 \%$ constituted other positions in the family.

As shown in table 2, majority (83.3\%) of respondents reportedly take adequate diet. Considering the frequency of daily food intake, only 1.7\% reported eating once a day, $13.7 \%$ reportedly eat twice a day, $60.0 \%$ reported eating thrice a day and $25.0 \%$ reported eating four times a day. Adolescents who reported that they eat in-between meals of snacks, drinks etc were $73.3 \%$. Majority (68.3\%) reported eating special diet only when sick. Many (70.0\%) of the adolescents reportedly eat what is needed to stay healthy.

Table 1: Socio-demographic characteristics of respondents, $N=60$

\begin{tabular}{|c|c|c|c|}
\hline $\mathrm{S} / \mathbf{N}$ & Questions & Frequency(n) & Percent (\%) \\
\hline 1. & 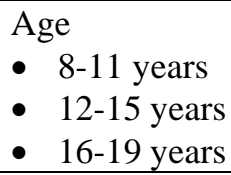 & $\begin{array}{l}14 \\
26 \\
20\end{array}$ & $\begin{array}{l}23.3 \\
43.3 \\
33.3 \\
\end{array}$ \\
\hline 2. & $\begin{array}{l}\text { Sex } \\
\text { - Male } \\
\text { - Female }\end{array}$ & $\begin{array}{l}29 \\
31\end{array}$ & $\begin{array}{l}48.3 \\
51.7\end{array}$ \\
\hline 3. & \begin{tabular}{cr}
\multicolumn{2}{c}{ Occupation } \\
- $\quad$ Student \\
\end{tabular} & 60 & 100.0 \\
\hline 4. & $\begin{array}{ll} & \text { Religion } \\
\text { - } & \text { Christian } \\
\text { - Islam }\end{array}$ & $\begin{array}{l}57 \\
3 \\
\end{array}$ & $\begin{array}{l}95.0 \\
5.0\end{array}$ \\
\hline
\end{tabular}

Table 2 Frequency distribution of pattern and practice of dietary intake of respondents N-60

\begin{tabular}{|c|c|c|c|}
\hline $\mathbf{S} / \mathbf{N}$ & Questions & Frequency(n) & Percent (\%) \\
\hline 1. & $\begin{array}{l}\text { Do you eat adequate diet? } \\
\text { - Yes } \\
\text { - No } \\
\end{array}$ & $\begin{array}{l}50 \\
10 \\
\end{array}$ & $\begin{array}{l}83.3 \\
16.7\end{array}$ \\
\hline 2. & $\begin{array}{l}\text { How many times do you eat in a day? } \\
\text { - Once } \\
\text { - Twice } \\
\text { - Thrice } \\
\text { - Four }\end{array}$ & $\begin{array}{l}1 \\
8 \\
36 \\
15\end{array}$ & $\begin{array}{l}1.7 \\
13.7 \\
60.0 \\
25.0\end{array}$ \\
\hline 3. & $\begin{array}{l}\text { Do you eat in between meals? } \\
\text { - Yes } \\
\text { - No }\end{array}$ & $\begin{array}{l}44 \\
16 \\
\end{array}$ & $\begin{array}{l}73.3 \\
26.7 \\
\end{array}$ \\
\hline 4. & $\begin{array}{l}\text { Do you eat special diet when sick? } \\
\text { - Yes } \\
\text { - No } \\
\text { - Occasionally }\end{array}$ & $\begin{array}{l}41 \\
15 \\
4\end{array}$ & $\begin{array}{l}68.3 \\
25.0 \\
6.7\end{array}$ \\
\hline 5. & Do you eat only what is needed to stay healthy? & & \\
\hline
\end{tabular}


South American Journal of Academic Research Special Issue May 2016

\begin{tabular}{|l|l|l|l|}
\hline$\bullet$ Yes & 42 & 70.0 \\
& $\bullet$ No & 18 & 30.0 \\
\hline
\end{tabular}
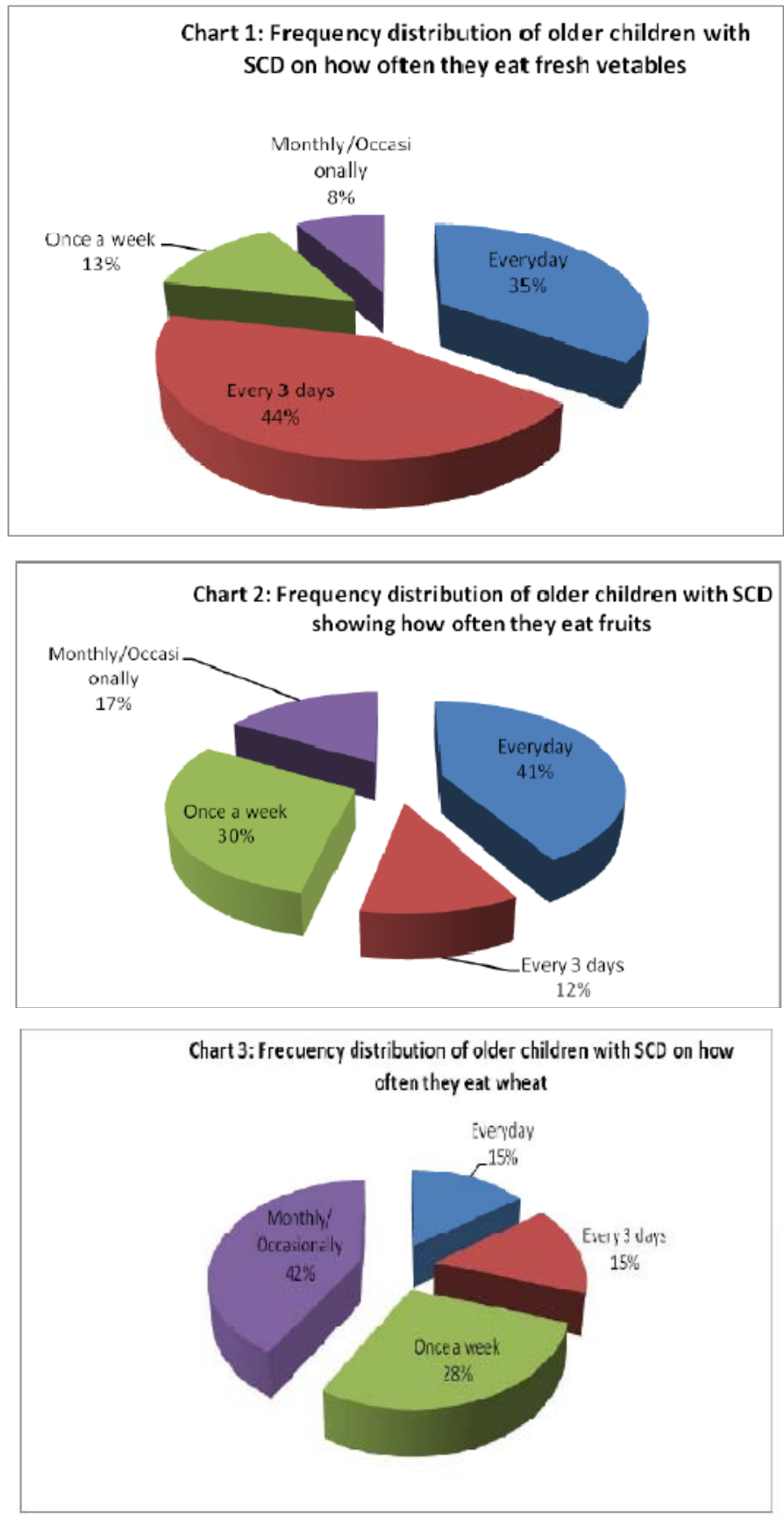


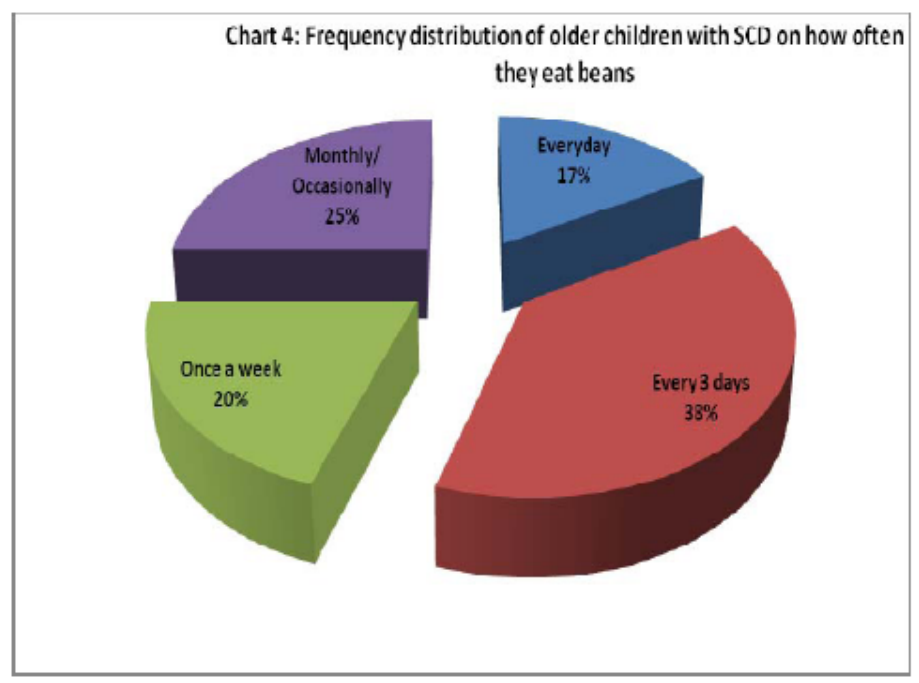

Chart 1 indicates how often adolescents with SCD eat vegetable. The highest number of respondents $26(44.0 \%)$ indicated every 3 days, followed by $21(35.0 \%)$ which indicated every day, 8 (13.0\%) indicated once a week and only few $5(8.0 \%)$ indicated once a month/ occasionally

Chart 2 shows that majority of the respondent 25 (41.0\%) indicated everyday, 18 (30.0\%) indicated once a week, 10 (17.0\%) indicated once month/ occasionally and 7(12\%) the least indicated every three days on how often they eat fruits

Chart 3 shows that 25 respondents $(42.0 \%)$ indicated that they eat wheat in their meals only once a month or occasionally, 17 (28.0\%) reported once a week, only 9 (15.0\%) indicated that wheat is included in their meals everyday and 9 (15.0\%) reported every 3 days.

The chart 4 shows how often adolescents in the study eat beans. Only ten (17.0\%) respondents indicated that their beans intake is on daily basis while $23(38.0 \%)$ indicated every 3 days, 12 (20\%) indicated once a week and 15 (25.0\%) indicated once a month/occasionally.

\section{Discussion/Conclusion}

\section{Summary of findings}

This study assessed dietary practices of older children who were mostly adolescents with sickle cell anemia at Sickle Cell Center, GRA, Benin City, Edo State Nigeria between October and November 2009. We described their socio-demographic characteristics and assessed the frequency of intake of food items such as fruits and vegetables, beans and wheat as well as in-between meals.

\section{Socio-demographic characteristics}

In this study, majority of the respondents (adolescents) were between the ages of 12-15 years and were mostly females, all of them were students and majority of these children were Christian while many had secondary level of education as expected for their age range. Respondents constitutes mostly of first and fourth born of their respective families. This study supports the fact that there is high incidence of occurrence of sickle cell disease among the fourth born of the family whose parent have a genotype AS (Aina and Onasoga, 2013).

\section{Pattern of dietary intake of adolescents with SCD as compared to their nutritional requirements.}

Patients with sickle cell anemia have greater than average requirements for both calories and micronutrients. This study showed that many of the adolescents reportedly take adequate diet and they take meals three times or more in a day. Many reported that they take inbetween meals in form of snacks and drinks. Majority reported that they take "special" diet 
South American Journal of Academic Research

Special Issue May 2016

when they are sick. This is a conflicting report as majority had initially reported that they take adequate diet. The need for a 'special' diet need not arise in the first place as all their diet should be adequate and contain essential elements not only because of the sickle cell disease but as adolescents. William et al (1997) reported that despite the fact that the adolescents are familiar with Food Guide Pyramid, most patients failed to consume appropriate amounts from those groups. Nutritional deficiencies and poor eating habits established during adolescence can have long-term consequences, including delayed sexual maturation, loss of final adult height, osteoporosis, hyperlipidaemia, and obesity from the adolescent's nutritional consideration. During sickle cell crisis, energy intake can be especially poor and this may be linked with the report of intake of 'special' diet when in crisis as reflected in this study

Most adolescents in this study do not take fresh fruits and leafy vegetables. In this study, many of the respondents eat food containing wheat only on monthly basis or occasionally. Only few take in food containing beans and beans product on daily basis.

It has been documented that a diet emphasizing fruits, vegetables, whole grains, and legumes will provide a greater proportion of essential nutrients than a typical western diet, and appropriate supplementation (1-3 times the recommended intakes for most essential nutrients) can prevent deficiency and may decrease the likelihood of disease exacerbation (Nutrition MD, 2015). The average energy intake of sickle cell patients is typically below the suggested allowance for calories during the quiescent phase of the disease and it drops to roughly half recommended levels during times of illness requiring hospitalization (Malinauskas, Gropper, Kawchak, et al., 2000). A good source of high calorie and nutrient dense (macro and micro nutrients) staple food, nationally available, and at a reasonable cost, is beans of different types. Although beans vary considerably in flavor, size, colour and shape, their nutritional composition is remarkably similar and it contains the following: calories, saturated fat, carbohydrate, protein, dietary fiber, sodium, thiamin, folic acid, copper, iron, magnesium, manganese, phosphorus, potassium. Studies have shown that vitaminmineral supplement of certain nutrients or treatment with a combination of high-dose antioxidants can reduce the percentage of irreversibly sickled cells (Marwah S. S, Blann A.D. Rea C., et al. 2002; Jaja, Ikotun, Gbenebitse, et al., 2002; Ohnishi, Ohnishi, Ogunmola, 2000; De Franceschi, Bachir, Galacteros, et al. 1997; Muskiet, Muskiet, Meiborg, et al., 1991; Glew, Casados, Huang, et al., 2002). Wheat is another food that is rich in manganese, phosphorus, magnesium and selenium, zinc, copper, iron and potassium and calcium. Wheat is also rich in vitamin B6, niacin, thiamin, folate, riboflavin and panthothenic acid. Vitamin E and $\mathrm{K}$ are also present in smaller but significant amounts. It also has phytonutrients, which promote better health through maintaining high blood cell counts (Organic Information services, 2015).

\section{Limitation of study}

We encountered poor co-operation from the respondents, as well as the general weakness of the respondent which prevented them from answering the questions posed and were without any significant other at the time of interview.

\section{Conclusion}

This study has shown that older children with sickle cell disease do not adequately eat diet that are beneficial to their health and good sources of macro and micronutrients evidenced by the poor irregular intake of fruits, vegetables, beans and wheat products though they claimed to be taking adequate diet. The health care team therefore should provide adequate information of daily dietary requirement to significant others looking after older children with sickle cell disease. This is due to the fact that older children with sickle cell disease do not practice adequate diet for the promotion of their health and minimizing the frequency of sickle cell crisis. In addition, emphasis need to be placed in intake of adequate diet regularly and not just the intake of 'special diet' when they are in crisis. 


\section{References}

[1.] Aina R. O. and Onasoga O. A. (2013) Perception of Pain among adolescents with sickle cell disease in Benin city, Edo state, Nigeria. Pelagia Library: European Journal of Experimental Biology 2013, 3(1): 401-405

[2.] Ashara Calisse-Atchley Cashaw, 2013. Feasibility of a Nutrition Training Program on Improving Self-Efficacy and life skill Development for adolescents with Sickle Cell disease - Unpublished dissertation for Doctor of Psychology, Philadelphia College of Osteopathic Medicine, Depatment of Psychology.

[3.] de Franceschi L, Bachir D, Galacteros F, et al. Oral magnesium supplements reduce erythrocyte dehydration in patients with sickle cell disease. J Clin Invest. 1997;100:1847-1852.

[4.] de Franceschi L, Bachir D, Galacteros F, et al. Oral magnesium pidolate: effects of long-term administration in patients with sickle cell disease. Br J Haematol. 2000;108(2):284-9.

[5.] Glew RH, Casados J K, Huang Y S, et al. The fatty acid composition of the serum phospholipids of children with sickle cell disease in Nigeria. Prostaglandins Leukot Essent Fatty Acids. 2002;67:217222.

[6.] Jaja SI, Ikotun AR, Gbenebitse S, et al. Blood pressure, hematologic and erythrocyte fragility changes in children suffering from sickle cell anemia following ascorbic acid supplementation. J Trop Pediatr. 2002;48:366-370.

[7.] Malinauskas B.M., Gropper S.S., Kawchak D.A., et al., 2000 Impact of acute illness on nutritional status of infants and young children with sickle cell disease. Journal of American Diet Association 2000:100:330-334

[8.] Marwah S. S, Blann A.D. Rea C., et al. Reduced Vitamin E antioxidant capacity in sickle cell disease is related to transfusion status but not to sickle crisis. American Journal of Heamatology, 2002:69:144-146

[9.] Muskiet FA, Muskiet FD, Meiborg G, et al. Supplementation of patients with homozygous sickle cell disease with zinc, alpha-tocopherol, vitamin C, soybean oil, and fish oil. Am J Clin Nutr. 1991;54:736-744.

[10.] Nutrition MD Healthcare Providers. 2015. Sickle Cell Disease: Nutritional Considerations. http://www.nutritionmd.org/consumenrs/heamatology/sickle_cel_nutriton.html Accessed 24/09/2015

[11.] Ohnishi ST, Ohnishi T, Ogunmola GB. Sickle cell anemia: a potential nutritional approach for a molecular disease. Nutrition. 2000;16:330-338.

[12.] Organic Information services Pvt ltd., 2015 Nutritional Value of Wheat and barley. https://www.organicfacts.net/nutrition-facts/nutritional-value-of-wheat-and-barley.html Accessed $16^{\text {th }}$ October, 2015.

[13.] Tomer A, Kasey S, Connor WE, et al. Reduction of pain episodes and prothrombotic activity in sickle cell disease by dietary n-3 fatty acids. Thromb Haemost. 2001;85(6):966-74 